will experience cultural dislocation. Both articles discuss the potentially beneficial role of traditional healers in assisting refugees. It would be interesting to learn more about the interface between traditional healing practices and psychiatric disorders associated with displacement and trauma. In this context, we need to be particularly vigilant about the needs of refugee children, whose development may have been harmed not only by their experiences but also by the associated famine and illness.

Finally, we have an article by Dr Mufti and colleagues concerning a chronic problem: refugees from the many years of conflict in Afghanistan who have moved across the border into Pakistan. The authors conducted a systematic study of refugee mental health in camps in Peshawar. They comment on the stress the large number of refugees has put on the fragile health service infrastructure in the host country, and they commend Pakistan for its positive response. The article reports a preliminary investigation that aimed to identify the prevalence of post-traumatic stress disorder. Rates were very high: indeed, most refugees seemed to be affected. This represents a similar story to that described in our papers on African refugees. There can be no doubt about the scale of the problem. Now, as psychiatrists who care about refugees within the international community, we should be working with our colleagues in the host countries to find the most efficient way of addressing it.

\title{
Refugee mental health challenges in Africa
}

\author{
Frank G. Njenga FRCPsych
}

President, African Association of Psychiatrists and Allied Professions, Upper Hill Medical Centre, 3rd Floor, Suite 3C, Ralph Bunche Road, PO Box 73749, Nairobi 00200, Kenya, email fnjenga@africaonline.co.ke

$\mathrm{N}$ early all low-income countries are either just themselves emerging from conflict or neighbour a country that has just emerged from one. According to the Office of the United Nations High Commissioner for Refugees (http://www.unhcr.org), of the 38 million uprooted people in 2003 worldwide, Africa played host to 13 million internally displaced persons and 3.5 million refugees.

The world's refugee burden is carried by the poorest countries. Significantly, of the 127 wars since the First World War, 125 have been fought in low-income countries, and 16 of the 20 poorest countries in the world have had a major conflict in the past 15 years. It is now accepted that, in Africa, conflict causes as many deaths as epidemic diseases. In addition, most of sub-Saharan Africa is listed by the World Bank as existing below the poverty line. It is therefore precisely these poor countries that have to share meagre resources with refugees and internally displaced persons. Given the link between psychological trauma, poverty and mental disorder, it is to be expected that refugee camps would have high rates of mental illness.

\section{Other contributors to the challenge}

Following political independence, many African countries enjoyed high levels of social and economic growth, before plunging into states of conflict, poor governance, corruption and, in some, total collapse of the central government authority - in the case Somalia for the past 13 years. In 1994, Rwanda experienced a genocide that lingers in the minds of all witnesses, African and non-African alike. Natural calamities such as droughts, famine, floods and earthquakes further contribute to high social morbidity. Terrorism has not spared the continent either (Njenga et al, 2004). Hitting the continent with increasing ferocity, mainly directed to women and the poorest, is HIV/AIDS, with current estimates showing 40 million infected. In some countries such as Botswana, the prevalence rates are up to $40 \%$ and life expectancy in some parts of Kenya have dropped from a high of 65 years before the pandemic to 38 years, in the process decimating the workforce, including that within the health services.

\section{Mental health, poverty and special groups}

It is now well established that poverty is an independent predictor of poor mental health (Holzer et al, 1986; Muntaner et al, 2004). It is also well established that particular groups in the population have higher rates of mental disorder, especially depression - for example, abused women, people living in extreme poverty such as slum dwellers, persons traumatised by conflict and war, migrants, and children and adolescents with disrupted nurturing, as well as indigenous groups. Of great significance is the fact that many of the well established vulnerabilities occur simultaneously in the same individuals.

\section{Post-traumatic stress disorder in Africa}

In the past few decades, the people of Africa have had many wars fought in their midst (Njenga et al, 2003). In a study from Rwanda, Pham et al (2004) found prevalence rates of post-traumatic stress disorder (PTSD) of $24.8 \%, 8$ years after the 1994 genocide. Among the survivors of torture, this rose 
to $36 \%$. In nearby Sudan, Peltzer (1999) found rates of PTSD as high as $32 \%$ among the residents of a refugee camp. In a study of internally displaced persons in Kenya, Njau (2005) found rates as high as $80.2 \%$ among heads of household.

All these reports point to the expected high prevalence rates not only of PTSD but also of comorbid disorders, including depression, substance and drug misuse, as well as other concomitants of the disintegration of social cohesion. In attempting to rebuild such communities, it will be important to understand how traumatic experiences may shape the ability of individuals and groups to respond to judicial and other reconciliation initiatives.

\section{The challenge}

Africa must respond to the seemingly insurmountable mental health challenge posed by refugees, the lack of resources not withstanding. Importantly, the response must be home grown, culturally relevant and appropriate, as well as affordable and sustainable. It must, in addition, be evidence based and open to both monitoring and evaluation. Account should be taken of the activities of the many groups of human rights activists who are always on the ground, seeking the promotion of their own agendas. The strategy must embrace local cultural norms and belief systems, ensure full community participation and integrate fully into the existing public healthcare systems. It should in its design include elements of building the human resource base of the community. Most African cultures accommodate diversity, curiosity and dialogue in their normal states and special attention must be paid to these issues.

The success of refugee programmes will be reflected in the extent of participation of the native community. Key among these will be traditional healers, who hold custody of much health-related wisdom in these communities.

School teachers are often forgotten in the planning of services, when it should be remembered that they are often the most educated members of the community as well as 'opinion leaders' in their own right; the success or failure of programmes could therefore depend on their involvement in the planning stages.

In many parts of Africa, formal and informal community groups could be invaluable in refugee programmes. They include self-help groups (for example those involved in water supply and housing) as well as women's groups, which in some communities can be very powerful in both social and resource mobilisation. Women's groups will be of especial importance because of their knowledge and experience in child refugee programmes as well as spiritual and guidance programmes with adolescent refugees.
In the response to this challenge, particular care must be taken not to give the impression that refugee status attracts entitlement to better or superior services, as this often leads to resentment among the host community. This is often grounded in the misconception by well meaning but ignorant non-governmental organisations that the refugees are their business whereas the host population is the business of the local government authorities. School-based and communitybased programmes for those with severe mental illness are often prone to some of these criticisms.

\section{Conclusion}

Refugees are often viewed as agents of environmental degradation, as well as people who arrive to share the meagre resources left after years of poverty, war and the plunder of national resources by political leaders, who are often the cause of the refugee problem in the first place.

All in all, the refugee problem is big and growing. No single strategy will be either suitable or sufficient: the approach must be multisectoral, multifaceted and multidisciplinary in nature.

The challenge is urgent, as in some countries it poses a threat to both security and national development, as tension mounts between the refugees and the host community. The world mental health community must stand together with the African people to rise to this challenge.

\section{References}

Holzer, C. E., Shea, B. M., Swanson, J. W., et al (1986) The increased risk for specific psychiatric disorders among persons of low socioeconomic status. American Journal of Social Psychiatry, 6, 259-271.

Muntaner, C., Eaton, W. W., Miech, R., et al (2004) Socioeconomic position and major mental disorders. Epidemiologic Reviews, 26, 53-62.

Njau, J. (2005) Post-Traumatic Stress Disorder Among the Heads of Households of Ethnic Clashes Survivors in the Rift Valley Province, Kenya: A Comparative Study. Thesis, University of Nairobi, Kenya.

Njenga, F. G., Kigamwa, P. \& Okonji, M. (2003) Africa: the traumatised continent, a continent with hope. International Psychiatry, 1 (1), 4-7.

Njenga, F. G., Nicholls, P. J., Nyamai, C., et al (2004) Post-traumatic stress after terrorist attack: psychological reactions following the US embassy bombing in Nairobi. Naturalistic study. British Journal of Psychiatry, 185, 328-333.

Peltzer, K. (1999) Trauma and mental health problems of Sudanese refugees in Uganda. Central African Journal of Medicine, 45, 110114.

Pham, P. N., Weinstein, H. M. \& Longman, T. (2004) Trauma and PTSD symptoms in Rwanda: implications for attitudes toward justice and reconciliation. JAMA, 292, 602-612.

\section{College website and international issues}

Readers are reminded that there is extensive coverage on the College website of international issues relevant to College members around the world (see http://www.rcpsych.ac.uk/college/internationalaffairsunit.aspx). Members are encouraged to send updates to Joanna Carroll by email (JCarroll@rcpsych.ac.uk). 